\title{
Investigation of The Effectiveness of Some Plant Compounds and Essential Oils of Corymbia Citriodora Against Foodborne Pathogens
}

\author{
Cemil Kürekci $^{1 *}$, Mustafa Yipel ${ }^{2}$, Sevda Pehlivanlar Önen ${ }^{1}$
}

${ }^{1}$ Department of Food Hygiene and Technology, Faculty of Veterinary Medicine, Mustafa Kemal University, 31120 Hatay, Turkey ${ }^{2}$ Department of Pharmacology and Toxicology, Faculty of Veterinary Medicine, Mustafa Kemal University, 31120 Hatay, Turkey

\section{A R T I C L E IN F O}

Article history:

Received 15 June 2016

Accepted 05 October 2016

Available online, ISSN: 2148-127X

Keywords:

Milk

E. coli,

L. monocytogenes

Antimicrobial

Essential Oil

Corresponding Author:

E-mail: ckurekci@hotmail.com \begin{abstract}
A B S T R A C T
The purpose of this study was to determine the antibacterial activity of plant derived compounds and essential oils of Corymbia citriodora against selected Gram negative and Gram positive foodborne pathogens in broth dilution assay. The combination of compounds (cineole, terpinen-4-ol and $\alpha$-terpineol; $\mathrm{CT} \alpha \mathrm{T}$ ) were further tested at three different concentrations $(0.2,0.4$ and $0.8 \%$ ) for the killing effect against E. coli $0157: \mathrm{H} 7$ and L. monocytogenes in milk including whole fat and skim fat. CT $\alpha \mathrm{T}$ showed antimicrobial activity against all bacteria tested at minimum inhibition concentrations (MICs) from $0.125 \%$ to $1 \%$ in broth dilution assay. Linalool was also found to be antimicrobial at MICs between $0.25 \%$ and $2 \%$, but not for Enterococcus casseliflavus. Further study carried out in milk showed that CT $\alpha \mathrm{T}$ at concentrations of $0.4 \%$ and $0.8 \%$ significantly reduced the population of $E$. coli $0157: \mathrm{H} 7$ under detection limit in skim milk, whereas it was only effective at $0.8 \%$ in whole fat milk. CT $\alpha \mathrm{T}$, on the other hand, shown to be less active towards L. monocytogenes as only significant effect was observed at $0.8 \%$ in skim milk. Taken together results of the present study indicate that plant derived compounds could be valuable alternatives to inactivate foodborne pathogens in milk.
\end{abstract}

\section{Introduction}

Freshly drawn milk is expected to be contaminated with many microorganisms which can be derived from the udder of the mammal, environment and even later on from the processing. Some of the microorganisms in milk present a risk to human health, although some of them might even be useful in terms of dairy technology (Demarigny et al., 1996; Langer et al., 2012). In addition, the existence of bacteria in milk is of great importance not only from the standpoint of pathogenic organisms but also for spoilage organism (Huck et al., 2008). The nutrient content of the milk and its $\mathrm{pH}$ value make it an excellent source of growth for most microorganisms. The bacteria of concern for human health are the following Escherichia coli, Campylobacter spp., Salmonella spp., Listeria monocytogenes, Staphylococcus aureus and Shigella spp. (Langer et al., 2012). The other pathogenic bacteria including Bacillus cereus, Brucella spp. Coxiella burnetii and Yersinia spp. are also detected in raw milk (Claeys et al., 2013). Of these bacteria, L. monocytogenes and $E$. coli $\mathrm{O} 157 / \mathrm{H} 7$ so far have received the most attention because of their association with severe clinical symptoms from diarrhea and extra-intestinal diseases to even death (Kirk et al., 2015). In order to eliminate pathogenic microorganisms, heat treatment is most common and widely applied technique. Even though the number of reported outbreaks that involved milk as the known vehicle for transmission has been dramatically decreased due to the introduction of pasteurization practices, milk still continues to be a significant source for the bacteria of concern for human health (FDA, 2011, Schmid et al., 2007). According to the review done by Langer et al., (2012), there were 122 reported outbreaks associated with the consumption of contaminated dairy products between 1993 and 2006, resulting in 202 hospitalized patients and two deaths in the USA. It is also well known fact that the exact number of illnesses from consumption of contaminated milk is hard to estimate accurately due to unrecognized or sporadic cases.

It strongly appears that safety of milk have yet to be ensured in order to prevent food safety hazards. Therefore, it is prudent to find the sustainable preservative treatments in order to reduce or to eliminate pathogenic microorganisms in dairy products. The application of non-thermal strategies such as radiations, however, is not been utilized for the treatment of milk and milk products, even though there has been great interest in those as an emerging disinfectant (Farkas, 2006). In addition, preservative agents like hydrogen peroxide are not allowed to be utilized, as it has been proven to be not entirely safe for human consumption (Humberston and Krenzelok, 1990). There has been a growing demand to consume minimally and naturally processed foods 
including dairy products among people. One of the most important and popular natural antimicrobial source is extracts and compounds of plants which have been known for almost a hundred years to possess natural biological (Kubeczka, 2016). Essential oils (EOs) are natural volatile compounds extracted through steam distillation from the non-woody part of the plants and EOs make up a complicated mixture in which there are mainly terpenoids, flavonoids, and phenols (Franz and Novak, 2016). For the last two decades, there, thus, have been great attentions being paid to identify biologically active plant derived compounds and many of these studies reported a number of biological activities such as antimicrobial, antiviral, insecticidal, antifungal and antiparasitic (Buchbauer and Bohusch, 2016). Moreover, anti-inflammatory, antioxidant, antiulcerogenic and wound healing activities of the plants and plant derived compounds have also been shown (Lassak and McCarthy, 2001). With regard to increasing interest, the use of EOs in the food industry has been extensively evaluated due to the high activity against pathogenic contaminants in vitro and in vivo experiments. So that, the objectives of this study were to determine the antimicrobial activity of EOs from Corymbia citriodora (formerly called as Eucalyptus citriodora) and compounds including eugenol, linalool and blend of compounds (cineole, terpinen-4-ol and $\alpha$-terpineol named as $\mathrm{CT} \alpha \mathrm{T}$ for this study) against Gram negative and Gram positive foodborne pathogens. Survival of $E$. coli O157:H7 and L. monocytogenes in milk containing a combination of $\mathrm{CT} \alpha \mathrm{T}$ and stored at $4^{\circ} \mathrm{C}$ was also evaluated.

\section{Material and Methods}

\section{Bacterial Strains and Test Agents}

The following test organisms were used; Salmonella Typhimurium ATCC 14028, S. aureus ATCC 25923, L. monocytogenes N7144, Enterococcus casseliflavus ATCC 700327, E. coli ATCC 25922, E. coli O145, O26, O111, O103, O104 and O157:H7 (ATCC 43895). EOs obtained from C. citriodora, linalool, eugenol and CT $\alpha \mathrm{T}$ (mixture of cineole, terpinen-4-ol and $\alpha$-terpineol) used in this study were all provided from Alan Twomey (BioAust, Australia).

\section{MIC Determination of Test Agents}

To determine the in vitro antibacterial activity, minimal inhibitory concentration (MIC) was determined using broth microdilution method in liquid culture (Wiegand et al., 2008). Briefly, stock cultures of the organism at $-80^{\circ} \mathrm{C}$ were inoculated on Tryptone Soya Agar (TSA) and incubated for $24 \mathrm{~h}$ at $37^{\circ} \mathrm{C}$. Subsequently, colonies were cultured in Tryptone Soya Broth (TSB) at $37^{\circ} \mathrm{C}$ for $18-24 \mathrm{~h}$. The bacterial inoculum was prepared from an overnight culture. Stock solutions of each test agents were serially diluted in ethanol/ethoxylated castar oil (1/1 v/v). Each bacterial suspension $(190 \mu \mathrm{L})$ and diluted test agents $(10 \mu \mathrm{l})$ were then mixed in each well of 96-well plate. Bacterial cell density (about $1-2 \times 10^{6} \mathrm{cfu} / \mathrm{ml}$ ) was adjusted using
Mcfarland 0.5 turbidity standards and the final concentrations of agents ranged from 2 to $0.001 \%$, v/v in each well of the plate. Solvent served as growth control and its concentration used in the assay was $2 \%$. The last wells of plate treated with compounds without microorganism were used as a sterility control. The microplates were incubated at $37^{\circ} \mathrm{C}$ for $24 \mathrm{~h}$ under aerobic condition. Following incubation, MICs was determined using iodonitrotetrazolium chloride by exactly as described previously (Kurekci et al., 2013) and experiment was carried out three times for reproducibility.

\section{Inoculation and Analysis of Milk}

Ultra-high-temperature (UHT) sterilized whole (3\% fat) and skim milk (no fat) were purchased from a supermarket and the sterility of milk samples were assessed by surface plating $(0.1 \mathrm{ml})$ of milk onto TSA, followed by incubation at $37^{\circ} \mathrm{C}$ for $48 \mathrm{~h}$. The milk samples were spiked with inoculum of either $E$. coli O157:H7 or L. monocytogenes and $10 \mathrm{ml}$ of spiked milk samples were subsequently dispensed into each tube. In order to determine the initial counts of E. coli $\mathrm{O} 157: \mathrm{H} 7$ or L. monocytogenes in milk serially diluted spiked milk samples $(0.1 \mathrm{ml})$ were plated onto TSA. Plates were incubated at $37^{\circ} \mathrm{C}$ for $24 \mathrm{~h}$ and then colonies were counted. CT $\alpha \mathrm{T}$ was added into each tube at three different concentrations $(0.2,0.4$ and $0.8 \%)$. Sterile water and solvent were also added into tubes for negative and positive control, respectively. For each treatment including controls five replicate tubes were used. The samples were mixed by vortex and refrigerated at $4{ }^{\circ} \mathrm{C}$ and surviving bacterial populations were determined after 24 $\mathrm{h}$ by serial dilutions prepared and then plated on TSA. For each dilution, the plates were incubated at $37^{\circ} \mathrm{C}$ for $24 \mathrm{~h}$ and then colonies grown on the plates were counted.

\section{Statistics}

Microbial counts were converted into $\log _{10} \mathrm{cfu} / \mathrm{mL}$ and the data were presented as means with standard deviations of five replicate. Differences in the number of viable bacteria between control and treatments were determined by using one-way ANOVA (SPSS 21) with Tukey's multiple comparisons test. Values with $\mathrm{P}<0.001$ were considered significantly different.

\section{Results}

Results obtained in the current study revealed that all agents displayed antimicrobial activity at variable concentrations in broth dilution assay (Table 1). Among the test agents evaluated for their antimicrobial activity, $\mathrm{CT} \alpha \mathrm{T}$ were found to be the strongest with MICs ranging from $0.125 \%$ to $1 \%$ for all tested organisms. Linalool also showed activity with the MICs ranging from $0.25 \%$ to $2 \%$ towards all organisms except E. casseliflavus. Eugenol showed antimicrobial activity against $L$. monocytogenes, $S$. aureus and some $E$. coli strains at concentration of $2 \%$, but did not display activity against $S$. Typhimurium and E. casseliflavus at concentration of $2 \%$, which was the highest concentration used in the 
current study. The poorest overall antimicrobial activity was observed with the EO obtained from $C$. citriodora which only displayed activity towards L. monocytogenes, E. casseliflavus and E. coli ATCC and E. coli $0157 / \mathrm{H} 7$, while did not show activity against $S$. Typhimurium, $S$. aureus and other $E$. coli strains tested.

Table 2 shows the survival of $E$. coli $\mathrm{O} 157: \mathrm{H} 7$ and $L$. monocytogenes at $4^{\circ} \mathrm{C}$ in skim and whole milk treated with different concentrations of $\mathrm{CT} \alpha \mathrm{T}$. The sterility of UHT milk samples were confirmed before spiking. After spiking, the initial population of E. coli in whole and skim milk were $6.82 \pm 0.06$ and $6.56 \pm 0.07 \log _{10} \mathrm{cfu} / \mathrm{mL}$, respectively and the number of $L$. monocytogenes were $6.70 \pm 0.04,6.76 \pm 0.02 \log _{10} \mathrm{cfu} / \mathrm{mL}$ in whole and skim milk respectively. As shown in Table 2, the addition of $\mathrm{CT} \alpha \mathrm{T}$ at concentration $0.4 \%$ and $0.8 \%$ significantly decreased the E. coli $\mathrm{O} 157: \mathrm{H} 7$ population to the under detection limit compared with negative and positive controls $(\mathrm{P}<0.001)$. However, the addition of CT $\alpha \mathrm{T}$ at $0.8 \%$ was sufficient to reduce L. monocytogenes below the detection limit in skim milk $(\mathrm{P}<0.001)$. When whole milk samples were treated with $\mathrm{CT} \alpha \mathrm{T}$ at $0.8 \%$ and held at $4^{\circ} \mathrm{C}$ for $24 \mathrm{~h}$, the E. coli $\mathrm{O} 157: \mathrm{H} 7$ inactivation was more than $2.5 \log \mathrm{cfu} / \mathrm{mL}$ when compared to controls $(\mathrm{P}<0.001)$. The number of $L$. monocytogenes in whole milk samples was, however, not affected by CTaT treatment.

\section{Discussion}

The current study investigated the antimicrobial properties of EOs from $C$. citriodora, as well as some plant compounds, against Gram negative and Gram positive pathogenic bacteria including those very important for food industry. All test agents exhibited a variable degree of antimicrobial activity towards major foodborne pathogenic bacteria tested with different MIC values. Linalool had a MIC value of $0.25-0.5 \%, 0.5 \%$, $0.5 \%$ or $2 \%$ against $E$. coli strains, $S$. Typhimurium, $S$. aureus and L. monocytogenes, respectively. These results were found to be slightly higher than those of Carson and
Riley (1995). These researchers found $0.25 \%$ and $0.06 \%$ MIC values for linalool against $S$. aureus or E. coli, respectively. In addition, it was observed that eugenol had antimicrobial activity against $S$. aureus, L. monocytogenes and some E. coli serovars at concentration of $2 \%$, which was in accord with earlier studies on the in vitro effects of eugenol against Helicobacter pylori (Ali et al., 2005). This observation is also consistent with similar findings of Sanla-Ead et al., (2012) who reported MICs values for eugenol against several foodborne pathogens at a concentration between 12.5 and $50 \mu \mathrm{l} / \mathrm{mL}$. Nevertheless, our results for eugenol are contrast to results obtained by other authors who found much lower MIC values for several foodborne pathogens including Salmonella Typhi $(0.0125 \%)$, E. coli $(0.05 \%)$ and S. aureus $(0.1 \%)$ (Devi et al., 2010; Walsh et al., 2003).

There are many studies undertaken to explore the biological activities, content and composition of extracts and EOs obtained from $C$. citriodora (Cimanga et al., 2002; Lis-Balchin and Deans, 1997). In the current study, C. citriodora displayed weak antimicrobial activities against particularly Gram positive bacteria ( $L$. monocytogenes and E. caseliflour) and as well as some $E$. coli serovars. Similarly, Luqman et al., (2008) reported that EOs of $C$. citriodora had more stronger activity towards Gram positive bacteria than Gram negative bacteria at MIC values of 10 or $>10 \mathrm{mg} / \mathrm{mL}$. In addition, some studies have revealed that cineole, $\alpha$-terpinene and terpinen-4-ol had remarkable antimicrobial activity against foodborne pathogens (Kurekci et al., 2013; Thomsen et al., 2013). The results of many studies also indicated that the EOs are more effective than the major compounds derived from them (Cox et al., 2001; Loughlin et al., 2007). The development of resistance to complex mixture of pure compounds appears to be unlikely due to a complex activity of these compounds (Hammer et al., 2012). Therefore, we evaluated the antimicrobial efficacy of $\mathrm{CT} \alpha \mathrm{T}$ and found that $\mathrm{CT} \alpha \mathrm{T}$ had a remarkable activity against a variety of foodborne pathogens tested.

Table 1 Minimal inhibitory concentration $(\%)$ of $C$. citriodora EO and compounds using broth microdilution assay*

\begin{tabular}{|c|c|c|c|c|}
\hline \multirow{2}{*}{ Test organisms } & \multicolumn{4}{|c|}{ Test Compounds (MIC \%) } \\
\hline & C. citriodora & Eugenol & Linalool & $\mathrm{CT} \alpha \mathrm{T}$ \\
\hline E. coli $\mathrm{O} 157 / \mathrm{H} 7$ & 2 & NA & 0.5 & 0.25 \\
\hline E. coli $\mathrm{O} 145$ & $\mathrm{NA}^{\mathrm{a}}$ & 2 & 0.5 & 0.125 \\
\hline E. coli $\mathrm{O} 104$ & NA & NA & 0.25 & 0.125 \\
\hline E. coli $\mathrm{O} 103$ & NA & NA & 0.5 & 0.125 \\
\hline E. coli 026 & NA & 2 & 0.5 & 0.125 \\
\hline E. coli $\mathrm{O} 111$ & NA & 2 & 0.5 & 0.125 \\
\hline E. coli & 2 & 2 & 0.25 & 0.125 \\
\hline S. typhimurium & NA & NA & 0.5 & 0.25 \\
\hline S. aureus & NA & 2 & 0.5 & 0.5 \\
\hline L. monocytogenes & 1 & 2 & 2 & 1 \\
\hline E. casseliflavus & 2 & NA & NA & 1 \\
\hline
\end{tabular}

${ }^{\mathrm{a}} \mathrm{NA}$; No activity at highest concentration tested (2\%) 
Table 2 Survival of E. coli and L. monocytogenes $\left(\log _{10} \mathrm{cfu} / \mathrm{ml}\right)$ in milk containing CT $\alpha \mathrm{T}^{*}$

\begin{tabular}{|c|c|c|c|c|}
\hline \multirow{2}{*}{ Treatments } & \multicolumn{2}{|c|}{$\overline{E . ~ c o l i}$} & \multicolumn{2}{|c|}{ L. monocytogenes } \\
\hline & Skim Milk & Whole Milk & Skim Milk & Whole Milk \\
\hline P-Control & $\overline{6.77 \pm 0.03^{a}}$ & $\overline{6.79 \pm 0.14^{\mathrm{a}}}$ & $\overline{6.66 \pm 0.07^{a}}$ & $\overline{6.72 \pm 0.03}$ \\
\hline N-Control & $6.47 \pm 0.49^{\mathrm{a}}$ & $6.65 \pm 0.16^{\mathrm{a}}$ & $6.69 \pm 0.05^{\mathrm{a}}$ & $6.66 \pm 0.08$ \\
\hline $\mathrm{CT} \alpha \mathrm{T}(0.8 \%)$ & $\mathrm{ND}^{\mathrm{b}}$ & $3.95 \pm 0.13^{\mathrm{b}}$ & $\mathrm{ND}^{\mathrm{b}}$ & $6.92 \pm 0.27$ \\
\hline $\mathrm{CT} \alpha \mathrm{T}(0.4 \%)$ & $\mathrm{ND}^{\mathrm{b}}$ & $6.31 \pm 0.12^{\mathrm{a}}$ & $6.44 \pm 0.14^{\mathrm{a}}$ & $6.77 \pm 0.06$ \\
\hline $\mathrm{CT} \alpha \mathrm{T}(0.2 \%)$ & $6.30 \pm 0.22^{\mathrm{a}}$ & $6.75 \pm 0,10^{\mathrm{a}}$ & $6.74 \pm 0.06^{\mathrm{a}}$ & $6.78 \pm 0.08$ \\
\hline
\end{tabular}

"Values are means of five replicates. ND: No colonies detected on the agar plates., ${ }^{\mathrm{a}, \mathrm{b}, \mathrm{c}}$ Means with different superscripts on the column differ significantly (Tukey, $\mathrm{P}<0.001$ ).

Apart from the in vitro antimicrobial activities, we also investigated the application of CT $\alpha \mathrm{T}$ to reduce the $E$. coli $\mathrm{O} 157: \mathrm{H} 7$ and L. monocytogenes population in whole and skim milk. CT $\alpha \mathrm{T}$ was selected for this study as effectiveness of these compounds has already been proved against a wide variety of microorganisms in vitro. Our work showed that $\mathrm{CT} \alpha \mathrm{T}$ at concentration of $0.8 \%$ and $0.4 \%$ caused a significant reduction in the cell counts of E. coli $\mathrm{O} 157: \mathrm{H} 7$ whereas only $0.8 \%$ resulted in the same effect towards L. monocytogenes in skim milk. This result is in agreement with our results obtained in broth dilution assay. Similarly, Dikici et al. (2013) and Shah et al. (2013) have reported that L. monocytogenes was much more resistant to eugenol when compared to $E$. coli O157:H7 in çiğ köfte and milk. The antimicrobial concentration of eugenol in this study was much lower than those previously reported (Dikici et al., 2013; Shah et al. 2013; Yoon et al. 2011). Shah et al. (2013) reported that L. monocytogenes and E. coli O157:H7 were both completely inhibited in all milk samples (whole, reduced fat and skim) when eugenol concentration was increased to $6.5 \mathrm{~g} / \mathrm{L}$. However they found that eugenol at the level of $1.0,1.5$ and $2.0 \mathrm{~g} / \mathrm{L}$ failed to inactivate both bacteria.

It is noteworthy to report herein that the fat content of milk appears to have a significant effect on the antimicrobial activity of $\mathrm{CT} \alpha \mathrm{T}$ against tested bacteria. Similarly, Shah et al. (2013) and Yoon et al. (2011) informed that the inhibitory activity of plant derived compounds was decreased by the fat content of milk. It was suggested that fat globules can attached to the surface of bacterial cells resulting in the formation of barrier disabling the penetration of EO/compounds through the cell wall (Farbood et al., 1976). As noted earlier, the possible binding of milk fat with $\mathrm{EO}$ or compounds undoubtedly plays a role in limiting the effectiveness of these agents (Juven et al., 1994).

\section{Conclusion}

Milk and dairy products unfortunately continue to be one of the major sources of the bacteria of concern for human health even though the heat-treatment is often used to eliminate pathogen microorganisms present in raw milk. With increasing demands for organic foods, there has been also growing interest to explore for natural antimicrobial additives which are not harmful for human health and as well not altering the organoleptic properties of foods. According to the data obtained from the current study, significant reduction in the population of $E$. coli
O157/H7 and L. monocytogenes was observed in skim milk stored at $4^{\circ} \mathrm{C}$ for $24 \mathrm{~h}$. Taken together, the data obtained from studies in both in vitro and model food system suggest that freshly drawn milk might be treated with natural plant derived compounds prior to the introduction of heat treatment.

\section{Acknowledgement}

We thank Prof. Dr. Mehmet Çalıcıoğlu (Fırat University) and Assos. Prof. Dr. Ahmet Koluman for the donations of strains and Alan Twomey for EO and compounds.

\section{References}

Ali SM, Khan AA, Ahmed I, Musaddiq M, Ahmed KS, Polasa H, Rao LV, Habibullah CM, Sechi LA, Ahmed N. 2005. Antimicrobial activities of eugenol and cinnamaldehyde against the human gastric pathogen Helicobacter pylori. Ann. Clin. Microbiol. and Antimicrobials, 4: 1-7.

Buchbauer G, Bohusch R. 2016. Biological activities of essential oils. In: (Başer KHC, Buchbauer G). Handbook of essential oils: science, technology, and applications. $2^{\text {th }}$ Edition. New York. CRC Press. pp. 281-322.

Carson CF, Riley TV. 1995. Antimicrobial activity of the major components of the essential oil of Melaleuca alternifolia. J. Appl. Bacteriol., 78: 264-269.

Cimanga K, Kambu K, Tona L, Aspers S, De Bruyne T, Hemans N, Totte J, Pieters L, Vlietinck AJ. 2002. Correlation between chemical composition and antibacterial activity of essential oils of some aromatic medicinal plants growing in the Democratic Republic of Congo. J. Ethnopharmacol., 79: 213-220.

Claeys WL, Cardoen S, Daube G, De Block J, Dewettinck K, Dierick K, De Zutter L, Huyghebaert A, Imberechts H, Thiange P, Vandenplas Y, Herman L. 2013. Raw or heated cow milk consumption: Review of risks and benefits. Food Control, 31: 251-262.

Cox SD, Mann CM, Markham JL. 2001. Interactions between components of the essential oil of Melaleuca alternifolia. J. Appl. Microbiol., 91: 492-497.

Demarigny Y, Beuvier E, Dasen A, Duboz G. Influence of raw milk microflora on the characteristics of Swiss-type cheeses. I. 1996. Evolution of microflora during ripening and characterization of facultatively heterofermentative lactobacilli. Lait, 76: 371-387.

Dikici A, İlhak Oİ, Çalıcıŏlu M. 2013. Effects of essential oil compounds on survival of Listeria monocytogenes and Escherichia coli O157:H7 in çiğ köfte. Turk. J. Vet. Anim. Sci., 37: 177-182.

Farbood ML, Macneil JH, Ostovar K. 1976. Effect of rosemary spice extract on growth of microorganisms in meats. J. Milk and Food Technol., 39: 675-679.

Farkas J. 2006. Irradiation for better foods. Trends Food Sci. Tech., 17: $148-152$. 
Food and Drug Administration (FDA). 2011. Grade "A" pasteurized milk ordinance. Revision 2011. U.S. Department of Health and Human Services, Public Health Service, FDA.

Franz C, Novak J. Sources of essential oils, In: (Başer KHC, Buchbauer G). Handbook of essential oils: science, technology, and applications. $2^{\text {th }}$ Edition. New York. CRC Press. pp. 43-86.

Hammer KA, Carson CF, Riley TV. 2012. Effects of Melaleuca alternifolia (tea tree) essential oil and the major monoterpene component terpinen-4-ol on the development of single- and multistep antibiotic resistance and antimicrobial susceptibility. Antimicrob. Agents Chemother., 56: 909-915.

Huck JR, Sonnen M, Boor KJ. 2008. Tracking heat-resistant, coldthriving fluid milk spoilage bacteria from farm to packaged product, J. Dairy Sci., 91: 1218-1228.

Humberston DB, Krenzelok EP. 1990. Ingestion of 35\% hydrogen peroxide. J. Toxicol. Clin. Toxicol., 28: 95-100.

Juven BJ, Kanner J, Schved F, Weisslowicz H. 1994. Factors that interact with the antibacterial action of thyme essential oil and its active constituents. J. Appl. Bacteriol., 76: 626-631.

Kirk MD, Pires SM, Black RE, Caipo M, Crump JA, Devleesschauwer B, Döpfer D, Fazıl A, Fischer-Walker CL, Hald T, Hall AJ, Keddy KH, Lake RJ, Lanata CF, Torgerson PR, Havelaar AH, Angulo FJ. 2015. World health organization estimates of the global and regional disease burden of 22 foodborne bacterial, protozoal, and viral diseases, 2010: A data synthesis. PLOS Med., 12: 1-21.

Kubeczka KH. History and sources of essential oil research, In: (Başer KHC, Buchbauer G). Handbook of essential oils: science, technology, and applications. $2^{\text {th }}$ Edition. New York. CRC Press. pp. 5-42.

Kurekci C, Padmanabha J, Bishop-Hurley SL, Hassan E, Al Jassim RAM, McSweeney CS. 2013. Antimicrobial activity of essential oils and five terpenoid compounds against Campylobacter jejuni in pure and mixed culture experiments. Int. J. Food Microbiol., 166: 450-457.

Langer AJ, Ayers T, Grass J, Lynch M, Angulo FJ, Mahon BE. 2012. Nonpasteruized dairy products, disease outbreaks, and state laws-United States, 1993-2006. Emerg. Infect. Dis., 18: 385-91.

Lassak EV, McCarthy T. 2001. Australian medicinal plants. Sydney. New Holland Publishers.

Lis-Balchin M, Deans SG. 1997. Bioactivity of selected plant essential oils against Listeria monocytogenes. J. Appl. Microbiol., 82: 759-762.
Loughlin R, Gilmore BF, McCarron PA, Tunney MM. 2007. Comparison of the cidal activity of tea tree oil and terpinen-4-ol against clinical bacterial skin isolates and human fibroblast cells. Lett. Appl. Microbiol., 46: 428-433.

Luqman S, Dwivedi GR, Darokar MP, Kalra A, Khanuja SPS. 2008. Antimicrobial activity of Eucalyptus citriodora essential oil. Int. J. Essen. Oil Ther., 2: 69-75.

Devi KP, Nisha SA, Sakthivel R, Pandian SK. 2010. Eugenol (an essential oil of clove) acts as an antibacterial agent against Salmonella typhi by disrupting the cellular membrane. J. Ethnopharmacol., 130: 107-115.

Sanla-Ead N, Jangchud A, Chonhenchob V, Suppakul P. 2012. Antimicrobial Activity of cinnamaldehyde and eugenol and their activity after incorporation into cellulose-based packaging films. Packag. Technol. Sci., 25: 7-17.

Schmid D, Fretz R, Winter P, Mann M, Höger G, Stöger A, Ruppitsch W, Ladstatter J, Mayer N, de Martin A, Allerberger F. 2009. Outbreak of staphylococcal food intoxication after consumption of pasteurized milk products, June 2007, Austria. Wien. Klin. Wochenschr., 121: 125-131.

Shah B, Davidson M, Zhong Q. 2013. Nanodispersed eugenol has improved antimicrobial activity against Escherichia coli O157:H7 and Listeria monocytogenes in bovine milk. Int. J. of Food Microbiol., 161: 53-59.

Thomsen NA, Hammer KA, Riley TV, Van Belkum A, Carson CF. 2013. Effect of habituation to tea tree (Melaleuca alternifolia) oil on the subsequent susceptibitiy of Staphylococcus spp. To antimicrobials, triclosan, tea tree oil, terpinen-4-ol and carvacrol. Int. J. Antimicrob. Ag., 41: 343-351.

Walsh SE, Maillard JY, Russell AD, Catrenich CE, Charbonneau DL, Bartolo RG. 2003. Activity and mechanisms of action of selected biocidal agents on Gram-positive and -negative bacteria. J. Appl. Microbiol., 94: 240-247.

Wiegand I, Hilpert K, Hancock REW. 2008. Agar and broth dilution methods to determine the minimal inhibitory concentration (MIC) of antimicrobial substances. Nat. Protoc., 3: 163-175.

Yoon JI, Bajpai VK, Kang SC. 2011. Synergistic effect of nisin and cone essential oil of Metasequoia glyptostroboides Miki ex Hu against Listeria monocytogenes in milk samples. Food Chem. Toxicol., 49: 109-114. 